\title{
Obituary
}

\section{Duncan Forbes, 1922-1994}

It is with great sadness that we report the death of our friend and mentor, Duncan Forbes, who passed away on December 3rd, 1994 at the age of seventy-two. Forbes, a Fellow of Clare College, Cambridge, is well known to scholars of Hegel as the author of the Introduction to H B Nisbet's translation of Hegel's own Introduction to his Lectures on the Philosophy of World History (Cambridge: Cambridge University Press, 1975). However, he is perhaps best remembered by his students for the exhilarating lectures on Hegel and Marx which he gave at the University of Cambridge during the 1960s, 1970s and early 1980s. Forbes' great gift was to breathe life and fire into texts such as the Phenomenology of Spirit and the Philosophy of Right - texts which can overwhelm undergraduates with their abstractness - by showing, with inimitable verve and subtlety, how Hegel's seemingly abstruse analyses shed a penetrating light on the nature of mastery, civil society and the state, that is to say (as Forbes himself liked to put it), by showing how time and again "the metaphysician brings home the bacon".

Inspired by the work of Emil Fackenheim, Forbes approached Hegel through Christianity and the all-important idea that the universal is incarnated in, and so does not simply transcend or absorb, the realm of the particular. "Hegel's philosophy", he wrote, "can be seen as an exhaustive working out, in ever-increasing fullness and complexity, of every possible variation, each growing out of its predecessor, on this theme of the unity of universal and particular" (Intro to $L P W H, \mathrm{p} x \mathrm{x}$ ). Forbes drew on this idea to argue forcefully that the "concrete universality" of Hegel's state is one in which the freedom of particular individuals is realised, not negated, and that Hegelian historical reason works in and through the actions of particular people and civilisations and so has no purity or autonomy of its own. Such ideas are, of course, common now, but they were not so readily accepted in the Cambridge of the 1960s, and Forbes often had to struggle hard to gain acceptance for them amongst his colleagues.

As a historian, Forbes was especially concerned to show that Hegel (no less than his beloved Hume) "delve[d] deeply into the empirical realm of observed fact" (Intro to $L P W H$, p xxiv) and was not guilty of the charge of simple "apriorism" levelled at him by many commentators. Following J N Findlay, he perhaps played down rather too much the importance to Hegel of logical strictness and rigour; but this was because his overriding aim was to emphasise that Hegel's philosophy of the Absolute "is absolutely open to experience" (Intro to $L P W H$, p xiii) and that the power and persuasiveness of that philosophy lies in its ability to render intelligible the complexities of actual historical and political life.

Forbes was deeply committed to Hegel's vision of political and social life - he wrote that "only if one is an anarchist can one reject Hegel's philosophy of the state" (Intro to $L P W H$, p xxii) - though he also had a subtle eye for the historical limitations of Hegel's thought. He would thus engage sympathetically in his lectures with careful critics of Hegel, such as Avineri, Plant and Taylor, but he would vent extraordinary ire on those quick-reading, quick-judging able men - from whom God defend the history of ideas who, taking a quick look through the telescope, usually someone else's, feel competent to lecture the crowd, always ready to enjoy the deflating of large balloons, on the iniquities of a system which they have not begun to understand properly (Intro to $L P W H, \mathrm{p}$ vii).

On one memorable occasion the unstapled pages of an article by one such quickjudging man, an eminent sociologist who had made rather thoughtless remarks about 
Hegel, were flung unceremoniously across the class-room by Forbes, and fell like autumn leaves on to the bowed heads of the awe-struck students in attendance.

What Forbes demanded was never blind adherence to particular philosophical doctrines, but simply an appreciation for what he called in his book on Hume "the sheer thickness and complexity of the texture of the past" - of past events and of past writers (Hume's Philosophical Politics, (Cambridge: Cambridge University Press, p 1975, p vii)). It was when he felt that this appreciation was lacking that his anger would rise. Forbes felt especially drawn to writers like Hegel, Hume, Adam Ferguson and Adam Smith because they themselves evinced precisely such appreciation for the complexity of the past (and present) with which they were dealing. On the other hand, it was partly what he perceived to be a lack of such appreciation in the writings of Marx and Engels that caused him to be so dissatisfied with their work.

Forbes constantly stressed Hegel's debt to, and affinity with, the writers of the Scottish Enlightenment, and he devoted much of his academic life to making the eighteenth century Scottish "philosophical historians" better known. In 1966 he published an edition of Adam Ferguson's An Essay on the History of Civil Society, 1767 with Edinburgh University Press; in 1970 he published an edition of Hume's History of Great Britain, Volume One, containing the reigns of James 1 and Charles 1 with Pelican Books; and he also wrote several articles on Hume, Smith, James Mill and Sir Walter Scott. What connected Hume, Ferguson and Smith with Hegel, in Forbes' view, was their commitment to the idea of public-spiritedness, their recognition of the importance of political institutions for liberty, their recognition of the role played by economic and social factors in the "history of civilisation" (which, by the way, is a term Forbes uses explicitly in connection with Ferguson, Hume and Hegel), and their insight into the problems and difficulties with which modern liberty is associated. Unfortunately, Forbes never completed a major work exploring all these connections (the very demanding standards he set himself frequently kept him from publishing his ideas); but his lectures were full of highly original insights and provocative suggestions for others to follow. In this way, he served as an important pioneer in what has now come to be regarded as a major area of philosophical and historical research. Furthermore, he derived great satisfaction from precisely this pioneering role: "being on the frontier", he said, "is so exhilarating that it is its own reward" (letter to Norbert Waszek, 27 September 1989).

In his introduction to his edition of Ferguson's Essay, Forbes wrote that "man is happiest and best-adjusted when all his powers are called forth and stretched to the utmost in and for his community" ( $p$ xxix). If this is indeed true, then Forbes was the happiest of men: for his extraordinary interpretative and pedagogical powers were called forth and stretched, tirelessly, over three decades for the benefit of his colleagues, students and family. Those of us who were fortunate enough to have been taught by him, and to have been stretched in turn, remember him with the greatest affection and remain forever in his debt. 